\title{
Evaluation of municipal garbage as a component of potting media for economically important timber species seedlings for afforestation in tropics
}

Authors Info

K. Vidyasagaran ${ }^{1}$ and Vikas Kumar ${ }^{2 *}$

${ }^{1}$ Department of Forest Management and Utilization, College of Forestry, Kerala Agricultural University, Thrissur-680 656, India

${ }^{2}$ Department of Silviculture and Agroforestry, College of Forestry, Vellanikkara, Kerala Agricultural University, Thrissur-680 656, India

*Corresponding Author Email : vkskumar49@gmail.com

Key words

Biomass production,

Municipal garbage,

Potting media,

Timber species,

Vigour index

\section{Publication Info}

Paper received : 19.05 .2015

Revised received: 10.12.2015

Re-revised received: 16.07 .2016 Accepted: 16.07.2016
Abstract

Aim : To investigated the comparative effect of different potting media with different compositions on growth and vigour of Tectona grandis (Teak), Ailanthus triphysa (Matti) andSwietenia macrophylla (Mahogany) seedlings.

Methodology : To determine the effect of different following seven potting media were prepared by thoroughly mixing the following components viz. T1 - Soil: Sand : cow dung (1:1:1 ratio- control treatment); T2- Soil: Municipal waste (1:1); T3 - Soil: Coir waste (1:1); T4- Soil: Tea waste (1:1);T5 - Soil: Municipal waste: Sand (1:1:1); T6 - Soil: Coir waste : Sand (1:1:1) and T7 - Soil: Tea waste: Sand (1:1:1).Estimating the growth attributes, physiological parameters and nutrient content of different treatments of selected important timber species seedlings.

Results : Results indicated that $\mathrm{T} 1, \mathrm{~T} 7$ and $\mathrm{T} 2$ as the best combination of potting media tomanifest maximum performance of various growths attributes for teak, mahogany and matti, respectively. Indeed, treatments containing municipal waste and cow dung recorded aslightly higher value of nitrogen, phosphorous and potassium content at the end of the study period.

Interpretation : There is a lack of scientific data, effect of municipal garbage on the growth and vigour of tree seedlings, either in the nursery or in the plantation. This information may be helpful in production of healthy seedling of different growth characters such as nutrient uptake, biomass production, chlorophyll production and leaf growth behavior of seedlings.

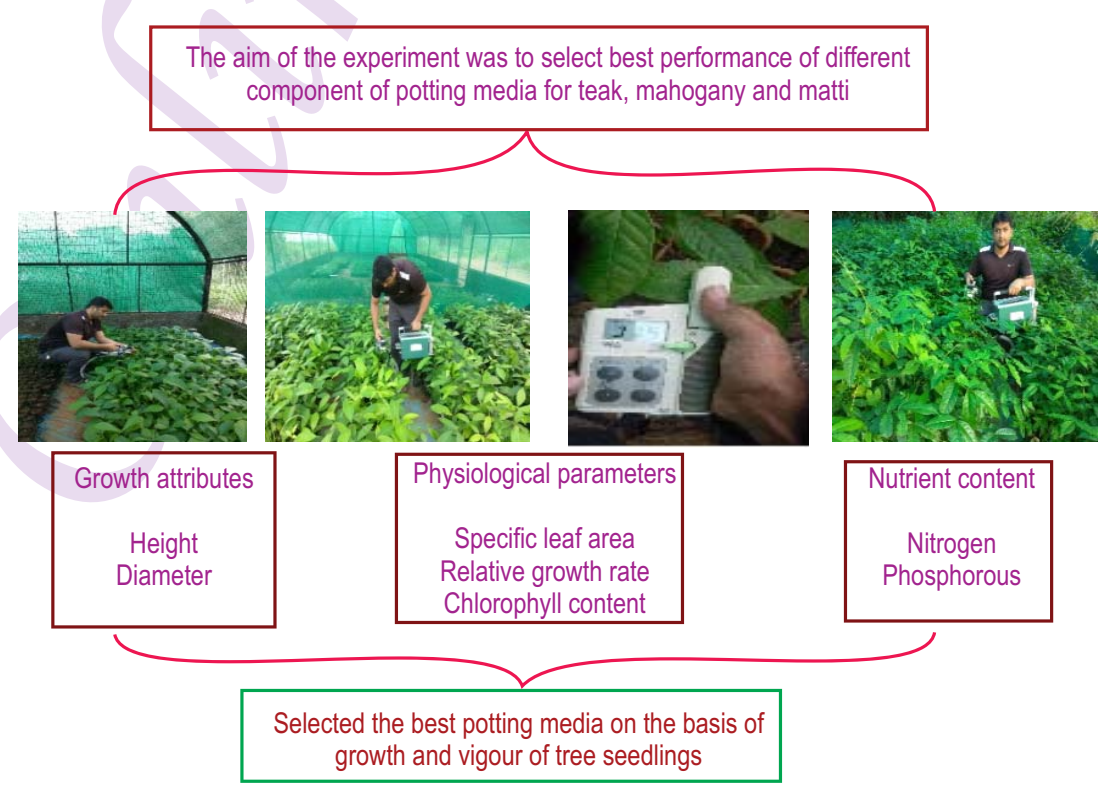




\section{Introduction}

India is facing the problems of pollution due to urbanization, population explosion, industrialization and other developmental activities. Uncontrolled urbanization and change in life style have contributed to a tremendous increase in per capita waste generation. Today solid waste including municipal garbage has caused serious problems in the disposal and has become a matter of serious concern just like air and water pollution (Sarkar, 2003; Ramachandra and Bachamanda, 2007).

Municipal waste management has become one of the most significant problems of urban and suburban areas because modern people way of life produced enormous amount of wastewhich is heterogeneous mixtures such as household wastes, construction and demolition debris, sanitary residues and wastes from the residential areas, street, mixture of paper, plastics, cloth, organic matter, hotels and hospitals etc. It includes commercial and residential wastes, generated in municipal or notified area (Ministry of Environment and Forest, 2000). Municipal garbage contains improper disposal of human and animal excreta, lacking of personal, food hygiene, lack of scientific solid and liquid waste management as well as hazardous chemical pollutants, which are causative of numerous disease injuries and perils, especially among the children, rag pickers and employees working in the waste management sector. Singh and Singh (2004) reported that rodent and insect vectors transmit diseases like Cholera, dysentery, infective hepatitis, plague, typhoid and others. The data showed the increasing trend to per capita solid waste generation ranged from 0.3-0.6 kg day ${ }^{-1}$ (CPCB, 2006) while in mid seventies it was just ranged from 0.15 $0.35 \mathrm{~kg}$ day $^{-1}$ (CPCB, 2000). Since these wastes are not being used for any purpose, it has created a real threat in not only for living environment in the townships but also suburban areas (Gopikumar, 2009).

In modern age, these wastes are defined as misplaced resources. Application of solid waste to soil provides an efficient and environmentally acceptable option of waste disposal, which also recycles valuable nutrients into the soil. Most of these materials are reported to be potential sources of wealth provided if they are exploited properly. The concept of organic matter recovery for use in agriculture and forestry is becoming more popular than land fill and incineration, since availability of chemical fertilizers to farmers at reasonable cost is fast declining. Application of this organic matter to enhances soil fertility and productivity (Rana et al., 2015).

Tectona grandis is also known as the king of timbers, it is a tropical hardwood and valuable timber species in the moist and dry deciduous forests of India (White 1991). The wood is highly durable, easily worked, attractive, strong and relatively light. Teak forests occur naturally in Asia Pacific region over an area of 23 million ha in India, Laos, Myanmar and Thailand. In India, it covers an area of around 9.77 million ha and this is around $13 \%$ of the total broad-leaved forests of India (Berbata, 1999).

Swietenia macrophylla (Meliaceae) is one of the most valuable tropical timber species in the world, fast growing (Bauer and Francis, 2000) andstrongly light demanding climax species (Gullison et al., 1996). It has been logged in a disorderly manner in natural forests, so that it was considered as endangered species and therefore included in CITES Appendix II. Its wood is almost non-refractory during drying (shrinkage almost equal radially and tangentially) and easily workable (Chudnoff, 1984); the heartwood is moderately resistant to dry-wood termites (Wolcott, 1946) and of unsurpassed natural beauty. In the recent times, Mahogany has gained a wide acceptance among the tree growers in Kerala (Kumar et al., 2015). In Kerala, despite the favourable agroclimatic and edaphic conditions and the concomitant production potential, the forest plantations contribute marginally to meet the state wood demand of less than 25\% (Krishnankutty 1990).

Ailanthus triphysa commonly known as matti, is a deciduous prominent multipurpose tree species in the traditional land use systems of Kerala, India (Kumar et al., 2001). It occurs in natural evergreen forests of Western Ghats too (PID, 1948). The very light and soft wood is utilized for making packing cases, catamarans, toys, and drums. Most important use is in match industry due to straight grain and without any deposition in wood.

The research studies revealed that the waste materials like municipal garbage could be used for growing ornamental plants (Wraga and Zawadzińska 2007, Macias et al., 2010, Erdogan et al., 2011, Zawadzińska and Salachna 2014). There is lacking of scientific data, effect of municipal garbage on the growth and vigour of tree seedlings either in the nursery or in the plantation. This information may helpful to production of healthy seedling of different growth characters such as nutrient uptake, biomass production, chlorophyll production and leaf growth behavior of seedlings. Hence, the present investigations were carried out to study the effect of two weeks partly decayed or stored waste materials as component potting media on the growth and vigour of Tectona grandis (Teak), Ailanthus triphysa (Matti) and Swietenia macrophylla (Mahogany) tree seedlings in the nursery.

\section{Materials and Methods}

The study was conducted at College of Forestry, Vellanikkara, Thrissur district, Kerala ( $13^{\circ} 31^{\prime} \mathrm{N}$ latitude and $76^{\circ} 13^{\prime}$ $E$ longitude and at an elevation of $40 \mathrm{~m}$ above sea level) during the period 2009-2013. Vellanikkara experiences a warm humid climate, having a mean annual rainfall of $2,670 \mathrm{~mm}$, most of which is received during the Southwest monsoon (June to August).

Mature mahogany pods were collected from the Wayanad district, Kerala. The collected pods were brought to the 
lab and seeds were extracted. Similarly, mature teak drupes were collected from three plantations of Nilambur Forest Division belonging to Malappuram district of Kerala $\left(10^{\circ} 15^{\prime}\right.$ to $10^{\circ} 26^{\prime} \mathrm{N}$ latitude and $75^{\circ} 33^{\prime}$ to $75^{\circ} 46^{\prime} \mathrm{E}$ longitude) and ailanthus seeds were obtained from Kerala Forest Research Institute, Peechi, Kerala ( $10^{\circ} 31^{\prime} \mathrm{N}$ latitude and $76^{\circ} 22^{\prime} \mathrm{E}$ longitude). The collected seeds were shade dried under room conditions for a day and store in an air tight polythene bags under room conditions. Before the initiation of the experiment the all collected seeds were first dipped in water and floated, chaffy seeds were discarded. The seeds were sown in nursery beds. The germinated seedlings of 5$8 \mathrm{~cm}$ height were transplanted to polybags $(11.43 \times 15.24 \mathrm{~cm}$, gauge 75 micron) containing different potting media and arranged in separate rows in the green house.

Indeed, the different potting media collected from different places. For instance, coir waste was collected from Coir mill, Kandassamkadavu,Thrissur, municipal waste materials were collected from drenching site of Thrissur Corporation and tea waste was collected from Tea factory, Wayanad district, Kerala. Although, municipal waste was kept two weeks for curing before preparing for the potting media. In order to determine the effect of different following 7 potting media were prepared by thoroughly mixing the following components viz. T1 - Soil: Sand: cow dung (1:1:1 ratio- control treatment); T2- Soil: Municipal waste (1:1); T3 - Soil: Coir waste (1:1); T4- Soil: Tea waste (1:1); T5 - Soil: Municipal waste: Sand (1:1:1); T6 - Soil: Coir waste: Sand (1:1:1) and T7 - Soil: Tea waste: Sand (1:1:1).

The experiment was laid out in randomized complete block experimental design with three replications. In all the substrates, partially decayed materials was used for removing the toxic substance present in the media. A total of 1500 seedlings were kept for conducting growth studies in the nursery. Seedlings after transplanted to the polybags were kept under greenhouse conditions. Necessary plant protection measures were also adopted.

Twelve seedlings belonging to each potting media were destructively sampled at the end of $8^{\text {th }}$ months and the shoot observations like height, girth and biomass of seedlings were recorded and simultaneously root fresh weight observations were made. Estimating the fresh weight, the shoot and root portion separated was dried in hot air oven at a temperature of $70^{\circ} \mathrm{C} \pm$ $2^{\circ} \mathrm{C}$ for about $48 \mathrm{hrs}$. Drying and weighing were continued till constant weight obtained. Quality index which is a measure to assess the quality of seedling based on the height, stem diameter and dry biomass was also calculated by the formula (Hatchell, 1985).

The physiological observations like number of leaves and fresh weight of leaves were taken at the end of eighth month. After oven drying, the dry weight of leaves was recorded. Drying and weighing was continued till constant weights were obtained.
Representative samples were taken from each treatment and leaf area and weight of leaves per plant were recorded and calculated specific leaf area by Kvet et al.(1971) and relative growth rate by Williams (1946). Indeed, leaf samples were collected from the selected plants and chlorophyll content was measured by chlorophyll meter.

The shoots of plants used for destructive sampling were dried and powdered. This fine powder was used for the estimation of nitrogen, phosphorous and potassium at monthly intervals. Ammonia was distilled by KEL PLUS automatic distillation system and nitrogen was estimated (Jackson, 1958). Phosphorous content was extracted calorimetrically by the Vanado- Molybdo Phosphoric yellow colour method (Jackson, 1958). Potassium content was determined by flame photometrically using potassium filter (Jackson, 1958).

Statistical analysis : The data was analyzed using the IBM SPSS statistics (version 20.0, SPSS Institute, Chicago, IL, USA) using one way analysis of variance. The treatment means were compared with LSD wherever necessary. Specific leaf area, relative growth rate chlorophyll content and nutrient content were also analyzed by the same method.

\section{Results and Discussion}

Analysis of variance revealed significant difference in height, collar diameter and seedling quality index due to the effect of various potting media. The availability of nutrients in growing substrate greatly affected the growth of seedlings. With regards to height, the maximum values were recorded for teak $(38.91 \mathrm{~cm})$ in $T 1$, mahogany $(56.10 \mathrm{~cm})$ in $T 7$ and ailanthus $(63.31 \mathrm{~cm})$ in $T 7$. The least height occurred in T3 for teak $(10.55 \mathrm{~cm})$ mahogany $(31.05 \mathrm{~cm})$ and ailanthus $(20.97 \mathrm{~cm})$ (Table 1). Stem with thickest diameter had more mechanical strength to resist breaking and bending against stress imparted by environmental conditions (Mehmood et al., 2013). However, highest collar diameter was observed for teak (10.22 mm) in T1, mahogany (9.35) in T1 and ailanthus $(14.87 \mathrm{~mm})$ in T2. The lowest collar diameter was observed for teak $(5.96)$ in T6, mahogany $(5.97)$ in T3 and ailanthus (6.72) in T6, respectively. Quality index is a measure to assess the quality of seedling based on the height, stem diameter and dry biomass. On the other hand, quality index was highest for teak (1.57) in T6, followed by mahogany (1.05) in T4 and ailanthus 1.54 in T4. The lowest quality index was observed for teak (1.01) in T4, mahogany (0.86) in T7 and ailanthus (0.82) in T6.A balanced rooting medium that contains an adequate supply of nutrients is essential for plants to attain maximum growth and development. Correct combination of substrates for growing media to optimize plant growth is demanding and represents the cost production about 4-6\% for bedding plants (Khan et al., 2012, Ikram et al., 2012). Results showed that use of different potting media affect plant height differently. With regards to height, maximum value was recorded by treatment T7 (Soil: Tea waste: Sand) in mahogany and ailanthus where as treatment T1 (Soil: 
Table 1: Growth attributes of selected important timber species seedlings (Teak, Mahogany and Matti) under different treatments in the nursery

\begin{tabular}{|c|c|c|c|c|c|c|c|c|c|}
\hline \multirow[t]{2}{*}{ Treatments } & \multicolumn{3}{|c|}{ Teak } & \multicolumn{3}{|c|}{ Mahogany } & \multicolumn{3}{|c|}{ Matti } \\
\hline & $\begin{array}{l}\text { Height } \\
\text { (cm) }\end{array}$ & $\begin{array}{l}\text { Diameter } \\
(\mathrm{mm})\end{array}$ & $\begin{array}{l}\text { Quality } \\
\text { index }\end{array}$ & $\begin{array}{l}\text { Height } \\
\text { (cm) }\end{array}$ & $\begin{array}{l}\text { Diameter } \\
(\mathrm{mm})\end{array}$ & $\begin{array}{l}\text { Quality } \\
\text { index }\end{array}$ & $\begin{array}{l}\text { Height } \\
\text { (cm) }\end{array}$ & $\begin{array}{l}\text { Diameter } \\
(\mathrm{mm})\end{array}$ & $\begin{array}{l}\text { Quality } \\
\text { index }\end{array}$ \\
\hline T1 & $38.91^{\circ}$ & $10.22^{c}$ & $1.04^{\circ}$ & $43.72^{d}$ & $9.35^{d}$ & $0.99^{\mathrm{a}}$ & $51.38^{c}$ & $13.78^{d}$ & $1.37^{\mathrm{ab}}$ \\
\hline T2 & $38.65^{c}$ & $9.19^{d}$ & $1.20^{\mathrm{ab}}$ & $48.78^{\mathrm{e}}$ & $8.20^{\circ}$ & $0.99^{\mathrm{a}}$ & $55.94^{\text {cd }}$ & $14.87^{\circ}$ & $1.53^{\mathrm{a}}$ \\
\hline T3 & $10.55^{\mathrm{a}}$ & $6.22^{\text {ba }}$ & $1.47^{\mathrm{a}}$ & $31.05^{\mathrm{a}}$ & $5.97^{\mathrm{a}}$ & $0.99^{\mathrm{a}}$ & $20.97^{\mathrm{a}}$ & $7.88^{\mathrm{b}}$ & $1.10^{\circ}$ \\
\hline T4 & $31.58^{b}$ & $6.45^{b}$ & $1.01^{\mathrm{c}}$ & $41.87^{\circ}$ & $8.33^{\mathrm{a}}$ & $1.05^{\mathrm{a}}$ & $42.22^{b}$ & $12.66^{c}$ & $1.54^{\mathrm{a}}$ \\
\hline T5 & $29.27^{b}$ & $6.55^{\mathrm{b}}$ & $1.15^{b}$ & $52.02^{f}$ & $8.46^{\mathrm{a}}$ & $1.00^{\mathrm{a}}$ & $53.99^{c}$ & $14.40^{\mathrm{de}}$ & $1.42^{\mathrm{a}}$ \\
\hline T6 & $11.60^{\mathrm{a}}$ & $5.96^{\mathrm{a}}$ & $1.57^{\mathrm{a}}$ & $36.73^{b}$ & $6.77^{\mathrm{b}}$ & $1.04^{\mathrm{a}}$ & $21.18^{\mathrm{a}}$ & $6.72^{\mathrm{a}}$ & $0.82^{d}$ \\
\hline T7 & $26.94^{b}$ & $8.70^{\circ}$ & $1.22^{\mathrm{ab}}$ & $56.10^{9}$ & $9.02^{d}$ & $0.86 a^{b}$ & $62.31^{\mathrm{d}}$ & $13.98^{\mathrm{d}}$ & $1.36^{\mathrm{ab}}$ \\
\hline
\end{tabular}

*Significant at 0.05 levels; Means with same letter as superscript are homogeneous

Table 2 : Physiological parameters among different treatments of selected important timber species seedlings (Teak, Mahogany and Matti) in the nursery

\begin{tabular}{|c|c|c|c|c|c|c|c|c|c|}
\hline \multirow[t]{2}{*}{ Treatments } & \multicolumn{3}{|c|}{ Teak } & \multicolumn{3}{|c|}{ Mahogany } & \multirow[b]{2}{*}{$\begin{array}{l}\text { Specific } \\
\text { leaf area }\end{array}$} & \multicolumn{2}{|l|}{ Matti } \\
\hline & $\begin{array}{l}\text { Specific leaf } \\
\text { area }\end{array}$ & $\begin{array}{l}\text { Relative } \\
\text { growth rate }\end{array}$ & $\begin{array}{l}\text { Chlorophyll } \\
\text { content }\end{array}$ & $\begin{array}{l}\text { Specific leaf } \\
\text { area }\end{array}$ & $\begin{array}{l}\text { Relative } \\
\text { growth rate }\end{array}$ & $\begin{array}{l}\text { Chlorophyll } \\
\text { content }\end{array}$ & & $\begin{array}{l}\text { Relative } \\
\text { growth rate }\end{array}$ & $\begin{array}{l}\text { Chlorophyll } \\
\text { content }\end{array}$ \\
\hline T1 & $16.42^{c}$ & $0.10^{a}$ & $59.77^{\text {bc }}$ & $24.05^{\mathrm{bc}}$ & $0.16^{\mathrm{ab}}$ & $51.63^{b}$ & $39.11^{\mathrm{ab}}$ & $0.01^{a}$ & $46.38^{b}$ \\
\hline T2 & $7.27^{\mathrm{a}}$ & $0.75^{b}$ & $62.47^{c}$ & $15.41^{a}$ & $0.20^{c}$ & $52.20^{b}$ & $28.27^{a}$ & $0.01^{a}$ & $46.07^{b}$ \\
\hline T3 & $21.19^{d}$ & $0.54^{\mathrm{ab}}$ & $47.60^{a b}$ & $25.68^{\mathrm{cd}}$ & $0.19^{b c}$ & $37.36^{\mathrm{a}}$ & $42.70^{\mathrm{ab}}$ & $0.02^{a}$ & $41.66^{\mathrm{a}}$ \\
\hline T4 & $5.97^{\mathrm{a}}$ & $0.18^{a}$ & $61.74^{\mathrm{c}}$ & $24.54^{\text {cd }}$ & $0.15^{\mathrm{a}}$ & $53.20^{b}$ & $40.99^{a b}$ & $0.01^{a}$ & $46.93^{b}$ \\
\hline T5 & $4.77^{\mathrm{a}}$ & $0.17^{\mathrm{a}}$ & $60.13^{b c}$ & $19.67^{\mathrm{ab}}$ & $0.20^{c}$ & $47.16^{b}$ & $39.79^{\mathrm{ab}}$ & $0.01^{a}$ & $47.66^{b}$ \\
\hline T6 & $11.09^{b}$ & $0.40^{\mathrm{ab}}$ & $44.53^{\mathrm{a}}$ & $28.82^{d}$ & $0.17^{\mathrm{ab}}$ & $35.33^{\mathrm{a}}$ & $45.52^{b}$ & $0.02^{\mathrm{a}}$ & $40.21^{\mathrm{a}}$ \\
\hline T7 & $18.19^{c}$ & $0.57^{\mathrm{ab}}$ & $65.29^{c}$ & $23.06^{b c}$ & $0.28^{d}$ & $47.90^{b}$ & $36.05^{\mathrm{ab}}$ & $0.01^{a}$ & $52.27^{\circ}$ \\
\hline
\end{tabular}

*Significant at 0.05 levels; Means with same letter as superscript are homogeneous

Table 3: The nutrient content of different treatments of selected important timber species seedlings (Teak, Mahogany and Matti) in the nursery

\begin{tabular}{|c|c|c|c|c|c|c|c|c|c|}
\hline \multirow[t]{2}{*}{ Treatments } & \multicolumn{3}{|c|}{ Teak } & \multicolumn{3}{|c|}{ Mahogany } & \multicolumn{3}{|c|}{ Matti } \\
\hline & $\mathrm{N}(\%)$ & $\mathrm{P}(\%)$ & $\mathrm{K}(\%)$ & $\mathrm{N}(\%)$ & $P(\%)$ & $K(\%)$ & $\mathrm{N}(\%)$ & $P(\%)$ & $K(\%)$ \\
\hline T1 & $2.02^{b}$ & $0.17^{\mathrm{a}}$ & $0.47^{b}$ & $0.59^{d}$ & $0.36^{b}$ & 0.75 & $1.35^{\mathrm{b}}$ & $0.31^{\mathrm{e}}$ & $0.74^{\mathrm{abc}}$ \\
\hline T2 & $2.33^{\circ}$ & $0.25^{\mathrm{a}}$ & $0.54^{b}$ & $0.46^{c}$ & $0.48^{\mathrm{d}}$ & 0.74 & $1.42^{\mathrm{b}}$ & $0.29^{d}$ & $0.69^{a}$ \\
\hline T3 & $1.04^{\mathrm{a}}$ & $0.16^{\mathrm{a}}$ & $0.20^{\mathrm{a}}$ & $0.37^{b}$ & $0.36^{b}$ & 0.62 & $0.77^{\mathrm{a}}$ & $0.15^{\mathrm{a}}$ & $0.69^{\mathrm{a}}$ \\
\hline T4 & $2.66^{\mathrm{d}}$ & $0.24^{\mathrm{a}}$ & $0.45^{\mathrm{b}}$ & $0.57^{d}$ & $0.38^{\mathrm{b}}$ & 0.84 & $1.70^{\circ}$ & $0.21^{\mathrm{a}}$ & $0.78^{\mathrm{c}}$ \\
\hline T5 & $2.27^{\circ}$ & $0.28^{\mathrm{b}}$ & $0.66^{\circ}$ & $0.76^{e}$ & $0.37^{b}$ & 0.51 & $1.48^{\mathrm{bc}}$ & $0.28^{d}$ & $0.78^{\circ}$ \\
\hline T6 & $1.17^{\mathrm{a}}$ & $0.15^{\mathrm{a}}$ & $0.24^{\mathrm{a}}$ & $0.28^{\mathrm{a}}$ & $0.30^{\mathrm{a}}$ & 0.45 & $0.83^{\mathrm{a}}$ & $0.18^{b}$ & $0.71^{\mathrm{ab}}$ \\
\hline $\mathrm{T7}$ & $2.36^{c}$ & $0.26^{a}$ & $0.55^{\mathrm{bc}}$ & $0.79^{\circ}$ & $0.44^{\circ}$ & 0.68 & $1.53^{b c}$ & $0.32^{\mathrm{e}}$ & $0.76^{\mathrm{bc}}$ \\
\hline
\end{tabular}

$\mathrm{N}$-nitrogen, P-Phosphorus and K-Potassium; *Significant at 0.05 level; Means with same letter as superscript are homogeneous

Sand: cow dung - control treatment) showed maximum value in teak at the end of the study. Similar results were also observed in teak in a study conducted by Ribeiro et al. (2000); Wilson et al. (2002); Herrera et al. (2008); Tariq et al. (2012); Mehmood et al. (2013); Sharifian et al. (2014).Recorded observations showed that treatment with sand and coir pith (T3) was lowest height in all the three species. Interestingly, it recorded that the collar diameter of the seedlings of various potting media were showed different response in end of research. Maximum values were registered in both $\mathrm{T} 1$ and $\mathrm{T} 2$ in all the three species. However minimum collar diameter was recorded in T3 for mahogany and ailanthus, where as T6 showed lowest girth value in teak. Addition of coir waste to soil proved less influential on girth and height in three species. However in teak, lowest girth was represented in potting media with tea waste.

Analysis of variance revealed significant difference in specific leaf area, relative growth rate and chlorophyll content due to the effect of various potting media. An increase in SLAgenerally increase dry mass where decreases leaf thickness. With regards 
to specific leaf area, the highest values were observed for teak $\left(21.19 \mathrm{~cm}^{2} \mathrm{~g}^{-1}\right)$ in T3, mahogany $\left(28.82 \mathrm{~cm}^{2} \mathrm{~g}^{-1}\right)$ in T6 and ailanthus $\left(45.52 \mathrm{~cm}^{2} \mathrm{~g}^{-1}\right)$ in T6. Least specific leaf area occurred for teak $\left(4.77 \mathrm{~cm}^{2} \mathrm{~g}^{-1}\right)$ in $\mathrm{T} 5$, mahogany $\left(15.41 \mathrm{~cm}^{2} \mathrm{~g}^{-1}\right)$ in T2 and ailanthus $\left(28.27 \mathrm{~cm}^{2} \mathrm{~g}^{-1}\right)$ in T2, respectively. Relative Growth Rate (RGR) is a complex parameter determined by a number of physiological, morphological and biomass-allocation complexes. However, highest RGR was recorded for teak $\left(0.75 \mathrm{~g} \mathrm{~g} \mathrm{~g}^{-1}\right.$ day $\left.{ }^{-1}\right)$ in T2, mahogany $\left(0.28 \mathrm{~g} \mathrm{~g}^{-1}\right.$ day $\left.^{-1}\right)$ in $\mathrm{T} 7$ and ailanthus $\left(0.02 \mathrm{~g} \mathrm{~g}^{-1} \mathrm{day}^{-1}\right)$ in T3 \& T6 (Table 2). The lowest RGR was observed for teak $(0.10 \mathrm{~g}$ $\mathrm{g}^{-1}$ day $\left.^{-1}\right)$ in T1, mahogany $\left(0.15 \mathrm{~g} \mathrm{~g}^{-1}\right.$ day $\left.{ }^{-1}\right)$ in T4 and ailanthus ( $0.01 \mathrm{~g} \mathrm{~g}^{-1}$ day $\left.^{-1}\right)$ in T1, T2, T4, T5 and T7, respectively. Chlorophyll is a key biochemical component in the molecular apparatus that is responsible for photosynthesis. On the other hand, chlorophyll content was highest for teak (63.29) in $\mathrm{T} 7$, mahogany (53.20) in T4 and ailanthus (52.27) in T7, whereas, chlorophyll content was lowest for teak (44.53) in T6, mahogany (35.33) in T6 and ailanthus (40.21) in T6Quality index is a measure to assess the quality of seedling based on the height, stem diameter and dry biomass. Quality index was highest in T6 for teak and T4 for mahogany and ailanthus, respectively. Meanwhile, quality index were the lowest for mixture of soil: tea waste (T4), soil: tea waste: sand (T7) and soil: coir waste: sand (T6) for teak, mahogany and ailanthus, respectively. Maximum increase in number of shoots per plant highlighted vigorous vegetative plant growth. Nutrient rich growing media promotes the growth of plants. Sugar maple seedlings produced maximum shoot weight when it grown in green house medium (Sharifian et al., 2014). Effective utilization of available solar energy and also the availability of ample supply of nutrients especially, nitrogen might be a reason for better performance of seedlings grown in treatments $\mathrm{T} 5, \mathrm{~T} 2$ and $\mathrm{T} 1$, respectively.

Growth of teak was better in a medium containing black soil, sand and municipal garbage in 1: 1: 1 proportion (Yadav et al., 1982). Davis et al. (1990) revealed that there is a positive relationship between stored carbohydrates or photosynthates present in the stem and development of healthy root system. Similar result has observed in this study also. It observed that an equal proportion of soil, sand, and composted of municipal garbage was found to be better rooting percentage, more root number and length in mangium seedlings (Goswami, 1990). Likely, another research reported that treatments containing partially decomposed municipal waste showed performed better as compared to other treatments with regard to root growth parameters and physiological attributes in the case of Ailanthus triphysa seedlings (Gopikumar and Minichandran, 2002).

Specific leaf area, relative growth rate and chlorophyll content were considered as important criteria for measuring the growth and vigour of the seedlings. Major food manufacturing units in plants are leaves that are influenced by environmental conditions and soil is one of the factors which have prime importance in this regard. More number of leaves in plants reflects its good vigor and suitability of environment. Leaf fresh weight among various species revealed that soil: tea waste $T 7$ showed highest value for mahogany but treatment T4 and T2 showed maximum values for teak and ailanthus, respectively. The lowest value of fresh weight was recorded in treatment with sand and coir pith (T3) for all the species under study. While examining the response of leaf characters to various potting media treatments, performance proved better when sand was added along with soil and decomposed waste. The availability of nutrients in growing substrate greatly affects the size of leaves. Best substrate having adequate supply of nutrients can be used to accomplish significant results. Maximum increase in size of leaves shows adaptability of plants to soil. Herrrera et al. (2008) observed the number of leaves/seedling and leaf area was significantly higher in compost-containing mixtures. Contradicting to the above statement, no significant variations were found for specific leaf area (SLA) or leaf area ratio (LAR) between the substrates studied. It notices that addition of composted garbage improve nutrient availability which could be one of the reasons for better performance of the seedlings grown in potting media with decomposed garbage (Khalilian and Sullivan, 1997). It also observed that treatment with coir waste was found unsuitable with regards to leaf number and leaf fresh weight.

Chlorophyll content in leaf among selected species revealed that highest chlorophyll content was recorded in treatment T4 for mahogany and treatment $\mathrm{T} 7$ for teak and ailanthus. Lowest values were recorded in T6 for mahogany and T3 and T1 for teak and ailanthus, respectively. Similar trends found in teak seedlings when solid waste was used as a component of potting media (Gopikumar and Minichandran, 2003). The result showed the municipal and industrial waste may use the alternative potting media for mass production of seedlings. Sharifian et al. (2014) observed that $50 \%$ and $75 \%$ compost had no significant effect on chlorophyll content. Level of $100 \%$ compost decreased the total chlorophyll content.

Analysis of variance revealed significant difference in nitrogen, phosphorus and potassium content due to the effect of various potting media. The availability of nutrients in growing substrate greatly affects the growth of seedlings. With regards to nitrogen content in tissue, the highest values were observed for teak (2.66 \%) in T4, mahogany (0.79\%) in T7 and ailanthus (1.53 $\%)$ in T6. Least nitrogen content in tissue occurred for teak (1.04 $\%$ ) in T3, mahogany $(0.28 \%)$ in T6 and ailanthus $(0.77 \%)$ in T3. However, highest phosphorus content was recorded for teak $(0.28 \%)$ in T5, mahogany $(0.48 \%)$ in T2 and ailanthus $(0.32 \%)$ in T7. Lowest phosphorus content in tissue was observed for teak $(0.15 \%)$ in T6, mahogany $(0.30 \%)$ in T6 and ailanthus $(0.32 \%)$ in T3. On the other hand, potassium content in tissue was highest for teak $(0.66 \%)$ in T5, mahogany $(0.84 \%)$ in T4 and ailanthus $(0.78 \%)$ in T4 and T5. Potassium content was the lowest for teak $(0.20 \%)$ in T3, mahogany $(0.45 \%)$ in T6 and ailanthus $(0.69 \%)$ in T2 and T3 (Table 3). 
As part of the experiment, an effect of potting media on plant nutrients was studied in the nursery. Maximum nitrogen content $(2.66 \%)$ at the end of the study period was recorded in treatment T4 in teak when compared to mahogany $(17 \%)$ and ailanthus $(0.79 \%)$. The low phosphorus content $(0.24 \%, 0.21 \%$ and $0.44 \%$ ) in the potting media substantiated the highest nitrogen content in $\mathrm{T} 4$ for teak, matti and mahogany, respectively. Nitrogen is an essential element required for plant growth and reproduction. It ranks after carbon, hydrogen, and oxygen in requirement. Municipal waste contains maximum amount of nitrogen but overall it had no contribution to plant growth. This is because macro- and micronutrient availability may not be sufficient to support plant growth when the $\mathrm{pH}$ of the growth medium is high. In a similar potting media experiment, Kumar et al. (2014) reported that combination of neem seed cake with soil and sand in the ratio 2:1 was most effective in enhancing the seedling growth and biomass production of Dalbergia latifolia. In mahogany, treatment $\mathrm{T} 7$ showed highest nitrogen content. Presence of cow dung in the treatment $\mathrm{T7}$ increased the nitrogen availability of the potting media by adjusting the $\mathrm{C}$ : $\mathrm{N}$ ratio of the soil. Several studies have revealed that composting of garbage increases nutrient availability. The quantity and form of nitrogen present in manure or compost is important in shaping the quality of the material (Moldes et al., 2007, Ribeiro et al., 2000). This statement is applicable in the present study also. Moldes et al. (2007) evaluated the physiochemical properties inmunicipal garbage different combinations. No absolute level of organic matter is ideal in terms of compost quality, but rather the quantities must be viewed in relation to the age of the compost, its nitrogen content, and its intended use.

Similarly for phosphorus, at the end of the study period, treatment T2 $(0.48 \%)$ registered maximum value for mahogany, but T7 $(0.31 \%)$ and T5 $(0.28 \%)$ unveiled maximum value for ailanthus and teak respectively. Though, lowest phosphorous content was recorded by $T 6$ in all the species. Potassium content in seedlings among various species indicated that treatment T5 $(0.66 \%$ and $0.0 .21 \%)$ showed highest value for teak and ailanthus. Phosphorus which has been called the key to life is essential for cell division and for development of meristematic tissues and it is very important for carbohydrate transformation due to multitude of phosphorylation reaction and to energy rich phosphate bond (Lambers et al., 2000). However in mahogany, maximum $(0.84 \%)$ value was registered by treatment $\mathrm{T} 4$. It observed that when plant grown in Soil: Municipal waste: Sand (T5), it shows the highest concentration of potassium due to the presence of decomposed municipal waste. Organic matter in growing substrate and optimum amount of N, P and K manipulate the plant growth (Mehmood et al., 2013). Different potting media were used with different proportions and best results for plant growth and flower diameter were obtained when Leaf Mould and peat moss were used in combination with silt + topsoil. Such findings were also agreement with Riaz et al.(2008) who found that growing substrate with adequate availability of nitrogen and potassium with high increase in plant growth and flower diameter. In the present study, increased concentration of phosphorus in the seedlings grown in potting media containing decomposed garbage is due to increased availability of phosphorus in those medium. Mehmood et al. (2013) reported that balanced rooting medium that contains an adequate supply of nutrients is essential for plants to attain maximum growth and development. The increased concentration of nitrogen, phosphorous and potassium might be due to faster nutrient release from decomposed municipal waste and decomposed cowdung. In general, treatments containing municipal waste and cowdung recorded a slightly higher value of nitrogen, phosphorous and potassium content at the end of the study period.

The present study evaluated the performance of selected species with respect to the application of different combinations of waste materials. Results showed that for height, maximum value was recorded by treatment $T 7$ (Soil: Tea waste: Sand) in mahogany and ailanthus where as treatment T1 (Soil: Sand: cow dung - control treatment) showed maximum value in teak at the end of the study. For diameter growth, maximum values were registered in both $\mathrm{T} 1$ (Soil: Sand: cow dung - control treatment) and T2 (Soil: Municipal waste) in all the three species. In general, treatments containing municipal waste and cow dung recorded a slightly higher value of nitrogen, phosphorous and potassium content at the end of the study period.

\section{Acknowledgment}

We are thankful to the Environmental Management Agency, Kerala for the financial support throughout the project implementation period.

\section{References}

Bauer, G.P. and J.K. Francis: Swietenia macrophylla. In: Francis, J.K., Lowe, C.A., (Eds.), Bioecologı'a de A' rboles Nativos y Exo' ticos de Puerto Rico y las Indias Occidentales. RI'o Piedras, Puerto Rico. USDA Forest Service General Technical Report IITF-15. pp. 492-498 (2000).

Berbata, K.C.: Teak Ecology, Silviculture, Management and Profitability. International Book Distributors, Dehradun, India, p. 380 (1999).

Central Pollution Control Board (CPCB): Assessment of Status of Municipal Solid Waste Management in Metro Cities and States Capitals, Central Pollution Control Board, Ministry of Environment and Forests, New Delhi (2006).

Central Pollution Control Board (CPCB): Status of Municipal Solid Waste Generation, Collection Treatment, and Disposal in Class-I Citiesll, Central Pollution Control Board, Ministry of Environment and Forests, New Delhi (2000).

Chudnoff, M.: Tropical Timbers of the world. Agricultural Handbook No. 607, U.S. Department of Agriculture, Washington DC, pp. 466 (1984).

Davis, T.D., B.H. Haissig and N. Sukhla: Adventitious root formation in cuttings. Tree Physiology, 6, 241-243 (1990). 
Erdogan, R., Z. Zaimoglu, F. Budak and C. Koseoglu: Use of sewage sludge in growth media for ornamental plants and its effects on growth and heavy metal accumulation. J. Food Agric. Environ., 9, 632-635(2011).

Gopikumar, K. and Minichandran: Effect of potting media containing waste on the nursery performance of Ailanthus triphysa seedlings. My Forest, 38, 283-294 (2002).

Gopikumar, K. and Minichandran: Solid waste as a component of potting media for the seedlings of agroforestry tree species. Final report, ICAR ADHOC scheme, College of Forestry, Kerala Agricultural University, Thrissur, India, p. 158 (2003).

Gopikumar, K.: Effect of garbage on performance of rosewood (Dalbergia latifolia) seedlings in the nursery. Inter. J. Plant Sci., 4, 346-351 (2009).

Goswami, G.N.: Influence of different soil mixtures on nursery growth of some tropical forest tree species. The Indian Forester, 118, 952-960 (1990).

Gullison, R.F., S.N. Panfil, J.J. Strouse and S.P. Hubbell: Ecology and management of mahogany (Swietenia macrophylla King) in the Chimanes Forest, Beni, Bolivia. Botan. J. Linn. Soc., 122, 9-34 (1996).

Hatchell, G.E.: Production of bare root seedlings. In: Proceedings of Third Biennial Southern Silviculture Research Conference (Ed.: E. Shoulde). Altanta, pp. 395-402 (1985).

Herrera, F., J.E. Castillo, A.F. Chica and L.L. Bellido: Use of municipal solid waste compost (MSWC) as a growing medium in the nursery production of tomato plants. Biores. Technol., 99, 287-296 (2008).

Ikram, S., U. Habib and N. Khalid: Effect of different potting media combinations on growth and vase life of Tuberose (Polianthes Tuberosa Linn.). Pak. J. Agri. Sci., 49, 121-125(2012).

Jackson, M.L.: Soil Chemical Analysis. Prentice Hall India (Pvt) Ltd. New Delhi, p. 489 (1958).

Kevt, J., J.P. Ondok, Necas and P.G. Jarvis: Methods of growth analysis (Eds.: Z. Sestak, J. Catsky, P.G. Jarvis and W. Junk). Plant photosynthetic production, Manual of Method, pp. 343-391 (1971).

Khalilian, A. and M.J. Sullivan: Application of composted solid waste in cotton production. Proceeding of Beltwive Cotton Conference, New Orleans, p. 53 (1997).

Khan, Z., S.A. Tiyagi, I. Mahmood and R. Rizvi: Effects of N fertilization, organic matter and biofertilizers on the growth and yield of chili in relation to management of plant-parasitic nematodes. Tur. J. Bot., 36, 73-81, (2012).

Krishnankutty, C.N.: Demand and supply of wood in Kerala and their future trends. Research Report 67. Kerala Forest Research Institute, Peechi, Kerala, p. 66 (1990).

Kumar, B.M., J. Thomas and F.R. Fisher: Ailanthus triphysa at different density and fertiliser levels in Kerala, India: Tree growth, light transmittance and understorey ginger yield. Agrforestry Systems, 52, 133-144 (2001).

Kumar, V., R. Ajeesh and C.M. Jijeesh: Chemical seed pre-treatments for better germination and seedling growth of Swietenia macrophylla King. J. Env. Bio-Sci., 29, 367-372 (2015).

Kumar, V., S. Kumar, S.K. Jha and C.M. Jijeesh: Influence of de-oiled seed cakes on seedlings performance of East Indian Rosewood (Dalbergia latifolia Roxb.). Soil Environ., 33, 169-174 (2014).

Lambers, H., F.S. Chapin and T.L. Pons: Plant Physiology Ecology. Springer-Verleg New Yourk.Inc., pp. 540 (2000).

Macias, F.J., D.J. Arias, M.D. Vela, R. Solera and J.L. Garcia-Morales: Substitution of peat for composts of municipal wastes in growing media: effects on growth and nutrition of Euphorbia pulcherrima. In: 14th Ramiran International Conference: Treatment and Use of Non Conventional Organic Residues in Agriculture. Lisboa, Portugal, p.4 (2010).

Mehmood, T., W. Ahmad, K.S. Ahmad, Y. Shafi, M.A. Shehzad, and M.A.Sarwar: Comparative effect of different potting media on vegetative and reproductive growth of floral shower (Antirrhinum majus L.). Univ. J. Plant Sci., 1, 104-111 (2013).

Ministry of Environment and Forest: The Municipal Solid Waste (Management and Handling) Rules 2000, Ministry of Environment and Forests, GOI, New Delhi, India (2000).

Mohan, S., K.G. Prasa and G.N. Gupta: Fertilizer response of selected social forestry species under varying soil texture. The Indian Fore., 111, 49-57 (1991).

Moldes, A., Y. Cendo'n and M.T. Barral: Evaluation of municipal solid waste compost as a plant growing media component, by applying mixture design. Biores. Technol., 98, 3069-3075 (2007).

Pascal, J.A.: Comparison of fresh and composted organic waste in their efficacy for the improvement of arid soil quality. Bioresource Technol., 68, 255-264 (1999).

PID.: The Wealth of India. Vol I A-B. Raw materials, Publication and Information Directorate, New Delhi, India, p. 42 (1948).

Ramachandra, T.V. and S. Bachamanda: Environmental audit of municipal solid waste management. Int. J. Environ. Technol. Manage., 7, 369-391 (2007).

Rana, R., R. Ganguly and A.K. Gupta: An assessment of solid waste management system in Chandigarh city, India. Electr. J. Geotechn. Engin., 20, 1547-1572 (2015).

Rao, K.J. and M.V. Shantaram: Effect of the application of garbage on the soil plant system. Agricultural Review, 16, 105-116 (1995).

Riaz, A., M. Arshad, A. Younis, A. Raza and M. Hameed: Effect of different growing media on the growth and flowering of Zinnia elegans $\mathrm{CV}$. Blue Point. Pak. J. Bot., 40, 1579-1585 (2008).

Ribeiro, H.M., E. Vasconcelos and J.Q. dos Santos: Fertilisation of potted geranium with a municipal solid waste compost, Biores. Technol., 73, 247-249 (2000).

Ritchie, G.A.: Carbohydrate reserves and root growth potential in Douglas fir seedlings before and after cold storage. Cana. J. Plant Sci., 12, 905-912 (1982).

Riaz, A., M. Arshad, A. Younis, A. Raza and M. Hameed: Effect of different growing media on the growth and flowering of Zinnia elegans $\mathrm{CV}$. Blue Point. Pak. J. Bot., 40, 1579-1585 (2008).

Sarkar, P.: Solid Waste Management In Delhi - A Social Vulnerability Study. In: Proceedings of the Third International Conference on Environment and Health, Chennai, India (Eds.: J. Martin, V. Bunch, S. Madha and T. Vasantha Kumaran), pp. 451-464 (2003).

Sharifian, Z., A.A.M. Mood and N. Mohamadi: Effect of different ratios of municipal solid waste compost on growth parameters and yield of marigold (Calendula officinalis Moench.) and daisy (Bellis Perennis L.). Inter. J. Advan. Biol. Biomed. Rese., 2, 43-50 (2014).

Singh, D.N. and J. Singh: Studies on solid waste disposal and management:AReview, Annals of NAGI, 24, pp.74-88 (2004).

Tariq, U., S.U. Rehman, M.A. Khan, A. Younis, M. Yaseen and M. Ahsan: Agricultural and municipal waste as potting media components for the growth and flowering of Dahlia hortensis 'Figaro'. Turkish J. Bot., 36, 378-385 (2012).

White, K.J.: Teak: Some Aspects of Research and Development. FAO Regional office for Asia and the Pacific, RAPA Publications, Bangkok, Thailand, p.53 (1991.) 
Williams, R.F.: The physiology of plant growth with special reference to the concept of net assimilation rate. Annals of Botany, 10, 41-72 (1946).

Wilson, S.B., P.J. Stoffella and D.A. Graetz: Development of compost based media for containerized perennial. Sci. Horticu., 93, 311-320 (2002).

Wolcott, G.N.: A list of woods arranged in accordance with their resistance to the attack of the West Indian dry-wood termite Cryptotermes brevis Walker. Caribbean For., 7, 329-334 (1946).

Wraga, K. and A. Zawadzińska: Ocena wpływu podłoża z komunalnego osadu ściekowego na kwitnienie i wartość dekoracyjna chryzantemy wielkokwiatowej (Chrysanthemum $\times$ grandiflorum (Ramat.) Kitam.). Ochr. Środ. i Zasob. Natur., 31, 249-254 (2007).

Yadav, A.S., P.K. Khare and G.P. Mishra: Growth performance of Tectona grandis (L.) seedlings in different pot culture media. The Indian Forester, 5, 86-89 (1982).

Zawadzińska, A. and P. Salachna: The effect of substrates containing municipal sewage sludge compost on the accumulation of macrocomponents in Impatiens walleriana Hook. J. Elem., 19, 253-263 (2014). 